\title{
移動知 (Mobiligence)
}

人間, 動物, 昆虫などは, 様々な環境において適応的に行動することができる。このような適応行動能力は, 生物が生存する上で, 最も基本的で必須な知的機能である。この適応的行動能力は, 脳や身体の損傷によって 損なわれることが知られている。しかし，このような適応行動が発現するメカニズムはほとんど明らかになっ ていない。そこでその解明を目的とし，平成17年より 5 年間のプログラムとして，文科省科研費特定領域「身 体・脳・環境の相互作用による適当的運動機能の発現一移動知の構成論的理解一」(略称：移動知)が開始され た.

この研究では, 生物が動くことで生じる,「身体」と「脳」と「環境」の動的な相互作用によって適応的に行動す る知が発現するという作業仮説に基づいており，この考え方を「移動知」(Mobiligence) と呼んでいる，ロボティ クスでは, 認知主体はまず知覚を行い, 環境を認識し, それに基づき行動を計画し, 実行 (移動・運動)すると 考えるのに対し, 移動知では, 認知主体が能動的に動くことによって, 環境を知覚・認知するとともに, それ に基づいて，実時間で適応的な行動を動的に生成すると捉える。

従来の生物学の分析的アプローチでは, 運動中の状態を把握することは難しい。 そこで移動知研究では, 神 経生理学, 生態学などの生物学の方法論と, システム工学, ロボティクスなどの工学の方法論を融合させ, 動 的な生体システムモデルを構成するという，構成論的・システム論的アプローチを取る。様々な生物の個々の 具体的な適応行動を対象として, 環境の変化を認知し情報を生成するメカニズム(環境適応), 環境に対して身 体を適応させ制御するメカニズム (身体適応)，他者ならびにその集合体としての社会に適応させるメカニズム (社会適応)の解明とともに, それらの背後にある, 移動知生成の力学的共通原理の解明に向けた研究が行われ ている.

(東京大学 人工物工学研究センター 淺間 一)

\section{情報大航海}

経済産業省商務情報政策局において，「ITによる情報大航海時代の情報利用を考える研究会」が2005年12月よ り翌2006年 7 月まで開催され, 大学関連教官, 通信キャリア業者, ITベンダ, 放送・メディア業者, ベン チャー, 金融など多様な分野からの参加者により種々の議論がなされた。サーチエンジンはウェブ時代に扔い て, 羅針盤の役目をする根幹的な技術基盤であり，すべての産業への影響するところが少なくなく，現行の商 用サーチエンジンの後追いではない次世代の知的情報アクセスの開発は重要な意味を有することなどが議論さ れた。2006年 7 月, 「情報大航海プロジェクトコンソーシアム」が発足し, 約95の企業, 大学等の参画があり, 技術ワーキンググループとビジネスワーキンググループが設けられたが, 前者は更に多くのサブワーキンググ ループ(テキスト, リアル・ヘテロ, 情報家電, 収集解析基盤, コラボレーション, 医療・ヘルスケア応用, も のづくり応用)が構成され, 技術開発の方向性に関して, より具体的な議論が進められた。総合科学技術会議に おいて「情報大航海プロジェクト」は高い評価を得, 2007年 4 月より実際にプロジェクトが始動, モデルサービ ス実施企業の公募がなされ，7月に最終的に合計で10プロジェクトが採択された。これらは大きく，1)プライ バシー配慮した行動履歴などを利用した携帯電話や鉄道・バス等共通乗車カード等を利用したパーソナルサー ビス，2 ) 画像・映像検索, 対話型検索など新しいコンテンッアクセス技術を基とした次世代ウェブサービス， 3 ) リアルタイム情報, 医療情報などの高度活用による社会インフラのIT化による新しいソーシャルサービス, の 3 つに分類される. 現在, ウェブ上では画像・映像を含めた多種多様な情報が急速に増大し, 他方では, ウェ ブに限らないあらゆる分野(例：医療分野, 流通分野)でこれまで活用されてこなかった大量の情報が蓄積され たままとなっており，これら多種多様かつ大量の情報を有効に活用する手段へのニーズが高まっている. 本「情 報大航海プロジェクト」により, ウェブ情報に限らない多様な情報の融合による実用に供する価值創出にむけて 大きな航海の一歩が踏み出されたと言える.

（東京大学 生産技術研究所 喜連川 優） 